\title{
Effect of Individual Counselling on Academic Performance of Underachiever Pupils in Maimusari Public Primary School, Jere Local Government Area, Borno State, Nigeria
}

-Hamsatu Joseph PUR: Department of Vocational Education, Faculty of Education University of Maiduguri Borno State, Nigeria.

Lawas Adamu MBAHI: Department of Vocational Education Faculty of Education University of Maiduguri Borno State, Nigeria

Amos AUDU: Department of Vocational Education Faculty of Education University of Maiduguri, Borno State, Nigeria

ABSTRACT: The study sought to investigate the effect of individual counselling on academic performance of underachievers" pupil in Maimusari Public Primary School, Jere local Government Area, Borno State, Nigeria. The objectives of the study were to examine the nature and causes of underachievement in Maimusari Public Primary School, also the effect of individual counselling on academic performance of the underachiever pupils. Based on these objectives, two research questions and one null hypothesis were answered and tested respectively. Quasi-experimental design was used for the study. Twenty-two underachieving pupils were purposively sampled from the population of the study. Both questionnaire and interview were used as method of data collection; Effect of Individual Counselling on Underachievers in Public Primary Schools (EICUPPS) and interview schedule. The data collected was analysed using descriptive and inferential statistics. The findings of the study discovered that coming late to school, not having complete learning material, depression, anxiety and teachers" attitude in the classroom were the major causes of underachievement in Maimusari primary school. The study also revealed that individual counselling helped the pupils in overcoming their learning barriers. It is, therefore, concluded that individual counselling has significant effect on underachievement among pupils of public primary school in Maiduguri, Borno State. It is recommended among others that class teachers need to be oriented on how to identify underachieving pupils in their various classes and inform the appropriate authority for proper management.

Key words: Effect, Individual counseling, Underachievers and academic performance.

International Journal of Educational Studies

Vol. 2, No.3, pp. 171-180

2019

DOI: $10.53935 / 2641-533 x . v 2 i 3.119$

Corresponding Author: Hamsatu Joseph PUR Funding: This study received no specific financial support.

Article History:

Received: 8 August 2019

Revised: 13 September 2019

Accepted: 10 October 2019

Published: 12 Nover 2019

(2) 2019 by the authors; licensee Academic

Publishing Group

\section{Introduction}

Education is one of the most important aspects of human resource development. Every child should have the opportunity to achieve his or her academic potential. The academic performance of underachieving pupils in primary schools have been a general concern in recent times, within the educational arena despite efforts at improving the school curriculum and quality of teaching (Moja, 2000). It is generally noticed that at least $20 \%$ of children in a classroom get weak marks (Sunil \& Madhuri, 2005). Such underachieving students have often been labelled as "lazy" or "difficult". Teachers have been known to write them off as "unteachable." As a result the school counselling profession has 
transitioned through a developmental process of reorganization as well, with its traditional emphases yielding to a more broad-based structure of assisting school children and their care givers (Gysbers, 2001; Gysbers \& Henderson, 2006; Scarborough \& Luke, 2008). In order for school reform to be deemed efficacious, the underachiever's desire to improve is necessary therefore; student performances in a variety of areas must demonstrate genuine improvement.

Increased demands are being placed on educational counsellors to help students facing problems of underachievement. A counsellor is a professional who is trained to understand and interprets human behaviour, find out the aetiology of such behaviour and how the individual could be assisted to ensure acceptable and normal behaviour so as to function effectively in the world around him. School counsellors provide counselling programs in three critical areas: academic, personal/social, and career. Their services and programs help students resolve emotional, social or behavioural problems and help them develop a clearer focus or sense of direction (Shaterloo \& Mohammadyari, 2011).

Guidance and counselling is described as an enlightened process whereby people help people by facilitating growth and positive adjustment through self-understanding (Kolo, 2001). Akinade (2012) defined guidance and counselling as a process of helping an individual become fully aware of him/her self and the ways in which he is responding to the influences of his environment. It further assists him to establish some personal meaning for this behaviour and to develop and classify a set of goals and values for future behaviour. It is a process whereby an individual is helped through a relationship with a professionally prepared person to voluntarily change his behaviour, clarify his attitudes and goals so that his problems could be solved. Counselling is done in two ways; group counselling and individual counselling. In group counselling, the counsellor is involved with a group of counselees, While individual counselling is a process through which clients work one-on-one with a trained therapist in a safe, caring and confidential environment to explore their feelings, beliefs or behaviours, work through challenging or influential memories, identify aspects of their lives that they would like to change, better understand themselves and others, set personal goals, and work toward desired change. In addition, individual counselling may be preventive and curative to underachievement among primary school pupils. The Guidance/Counsellor believes in the individuality of people. To every individual is a unique person, who is capable of developing his potentials and capabilities to the fullest, if properly, guided.

Underachievement is wide-ranging and deeply embedded in the social and economic fabric. It is the responsibility of schools to provide an environment that will meet the social, emotional and learning needs of all pupils. The phenomenon of underachievement is global, with achievement level dropping in all academic work. While it is normal for everyone to aim at actualizing great targets, the fact remains that some may not realize their desire for great achievement due to difficulty in understanding materials taught, attention deficit and hyperactive, ill-health, impairment and the likes.

Rayneri, Gerber, and Wiley (2006) found that academic underachievement is a national problem in Nigeria and the world at large. In addition, Matthews and McBee (2007) indicated that the topic of underachievement has intrigued educators for quite some time and is an on-going concern. It seems that there is little consensus on how best to define underachievement. Donald, Lazarus, and Lolwana (2006) defined academic underachievement as performing below potential while (Reis \& McCoach, 2002) defined it as a discrepancy between ability and achievement. Underachievement is used to describe a situation where performance is below what is expected based on ability. It can apply at the level of an individual pupil or describe a class or school, or indeed a system. From these varying definitions it can be deduced that underachievers are a diverse population and that both gifted and non-gifted learners can underachieve.

In general, academic underachievement is defined as failure to meet the academic requirements of the school setting (Connor, 2002). One might think that underachieving learners lack motivation, but Reiss (2008) asserted that underachievers are highly motivated in directions other than getting good grades and finding out precisely where their motivation lies is the key to helping them turn around and become achievers at school. Labelling pupils as an underachiever ignores the positive outcome of those areas in which the pupils does succeed; it therefore makes more sense to label the area of underachievement, not the pupils. For example, a student may be underachieving in mathematics or science. Underachievement is tied to the self-concept which can become a self- fulfilling foresight. If

Vol. 2, No.3, pp. 171-180

2019

Corresponding Author: Hamsatu Joseph PUR Funding: This study received no specific

financial support.

Received: 8 August 2019

Revised: 13 September 2019

Accepted: 10 October 2019

(C) 2019 by the authors; licensee Academic

Publishing Group

| 172

\begin{abstract}
pupils see themselves as failures, they may eventually place self-imposed limits on what is possible. For
\end{abstract}


students in this category, good grades are dismissed as accidents or luck but poor grades serve to reinforce a negative self- concept.

Several factors are suspected to affect academic underachievement. These have been primarily arranged into two clusters, namely personal or individual-related factors and environmental factors. The personal factors may be physical, intellectual or emotional and environmental factors comprise of factors within the school or family. Matthews and McBee (2007) found that underachievement of learners is caused by the school environment. Students underachieve for a variety of reasons, the least of which is because they are lazy, difficult, unteachable or learning disabled. Underachievement is a symptom with multiple causes. The factors that contribute to them are complex and inter-related. These include individual attitudes, beliefs and expectations of pupils, parents and teachers. Closely linked to these are deep seated social challenges, such as institutional tribalism, urban regeneration, economic development and migration. However the gaps also persist because for too many pupils, school does not engage them or equip them with the skills they need. If pupils do not learn how to read effectively early on in school, they may have difficulty at later stages and may withdraw from learning rather than risk being exposed to shame. The visual memory problems are woefully under recognized as a source of school underachievement, this acknowledges that academic underachievement can also result from extracurricular circumstances that distract youngsters from paying attention to their schoolwork. Young people who fail to utilize their potential waste educational and occupational opportunities that are within their reach.

Effective individual counselling programs are important to the school climate and a crucial element in improving student achievement (Shaterloo \& Mohammadyari, 2011). Several studies found that elementary guidance activities have a positive influence on primary school students' academic achievement (Sink \& Stroh, 2003). Individual counselling interventions have reported success for helping students reduce test anxiety (Cheek, Bradley, Reynolds, \& Coy, 2002). Collaborative efforts can implement both systemic and programmatic changes in schools and communities to prevent students from underachieving in schools (Standard, 2003). Individual Counselling services also support teachers in the classroom and enable teachers to provide quality instruction designed to assist students in achieving high standards.

According to Bergin, Miller, Bergin, and Koch (1990) underachieving students continue to be an enigma to parents, educators, and sometimes to themselves. Often these students vow to perform better on the next unit, the next test or the next quarter report card, only to fall back into old underachieving patterns. Current brain research explains why, despite the best efforts of all involved, underachievement persists. The longer a person remains in a state (depression, procrastination, underachievement, etc.), the harder it is to change. It essentially becomes more comfortable to remain in the familiar state. To effectively break a negative cycle, psychologists often suggest that it is necessary to change an individuales $s$ thought patterns before attempting to develop more productive behaviours. Underperforming students benefit from knowledge about learning theory. They need to know that education is most effective when engagement is high and stress is low. Understanding this, they can then learn how to recognize when they are having difficulty engaging in assignments and identify when/if they are under undue stress. Once they are able to recognize these barriers, they can learn to mitigate them through positive self-talk, visualization, biofeedback, etc. Both the ability to engage and management of stress can be taught directly (Alzahrani \& Woollarrd, 2013).

Affirmations are positive statements that an individual says (either aloud or to himself) several times during the day. These statements empower and encourage. Repetition can become second nature and they can turn into self- fulfilling prophecies. Affirmations can be kept in places of prominence (on mirrors, on dashboards, on desktops, in pockets, on computer screens, etc.). Examples are as follows:

- I am a capable person.

- I can do the homework if I decide to do it.

- School is as meaningful as I make it.

- Grades allow me to reach my personal goals.

Many underachieving students have intractable (automatic) thoughts that are negative especially about homework and grades freezing them into inaction. Therefore, it is important to stop this pattern. The student first has to identify what interferes with performance and then he/she needs to learn to say,

2019

Corresponding Author: Hamsatu Joseph PUR Funding: This study received no specific financial support.

Received: 8 August 2019

Revised: 13 September 2019

Accepted: 10 October 2019

(C) 2019 by the authors; licensee Academic

Publishing Group

| 173 
"Stop" (aloud or in his/her mind), to put an end to this trend of thought. More concrete learners find a specific action works better, such as wearing a thick rubber band on one ${ }^{\text {ee }}$ s wrist. When the self-defeating idea occurs, he/she snaps his/her wrist with the rubber band, utilizing behaviour modification to decrease and eventually to eliminate unwanted thinking patterns. Once the young person is astutely aware of this negative habit, it is time to employ a strategy for changing/substituting to a more positive, productive behaviour (Ruel, 1997). Underachieving pupils often benefit from direct coaching. With the assistance of an adult facilitator, these young people are able to pinpoint and verbalize the exact thoughts that they experience when they begin the underachieving cycle. They are then encouraged to practice substituting more positive thought patterns.

In another exceptionally well-done comprehensive study, Brigman and Campbell (2003) used a quasi- experimental, pre post-test design to evaluate the impact of a school-counsellor led intervention on student academic achievement and school success behaviours. The Math and Reading scores from the Florida Comprehensive Assessment Test (FCAT) were used to assess academic improvement. The researchers randomly selected 185 experimental (treatment) group students and 185 comparison group students in grades 5, 6, 8, and 9, all of whom had initially scored between the 25th and 50th percentile on the FCAT. Students were selected from three elementary schools, one middle school, and two high schools.

Treatment group students participated in the Student Success Skills curriculum, which focuses on cognitive, social and self-management skills. Comparison group students were not exposed to the curriculum. The results of this study indicated a significant difference between treatment and comparison groups on reading and math scores. These results provide very strong support for the conclusion that school counselling interventions that focus on the development of cognitive, social and self-management skills can result in sizable gains in student academic achievement.

Research has highlighted that the work of schools counsellors needs to be monitored and evaluated regularly to ensure that high standards in service delivery are maintained (Pattison, 2007). However, it can be difficult to evaluate counselling interventions. Where improvements in terms of symptom reduction have been observed, isolating the extent to which the effects have occurred as a direct result of counselling can be almost impossible. Also, maturation can account for a significant amount of symptom reduction in children and young people; some may simply ,grow out of the problems for which counselling was received (Bond, 2004). Despite this, evaluations of school-based counselling have shown that services are widely perceived as being effective. The evaluation work undertaken by the Cabrini Children"s Society showed that the vast majority of children and young people, who had accessed their counselling services felt happier, less worried and that things were better at home and school since seeing the counsellor. 94 percent also reported that they would either probably or definitely go or see a counsellor again. All service users reported that the counsellor was easy to talk to and felt that they could be trusted to keep the matters discussed confidential. Less than one per cent of service users stated that the counsellor had not helped them with their problems, and that they had not understood their feelings.

All bar one of the head teachers in the schools which had hosted the Cabrini Childrenes Society ${ }^{\text {ee }}$ counselling service felt that it was valuable. Whilst 45 percent could not see that the counselling had much impact, they reported that they knew the work was helping. A further 60 percent reported that they had seen evidence of improvement in the pupils concerned. Only one negative response was obtained concerning the impact of the counselling for pupils, where a head teacher felt that little improvement had been incurred by the pupils referred for counselling. Staffs were seen to have benefited from the service the most through being able to refer children in need of the service and to consult with the counsellor about pupils who were a cause for concern, according to over three quarters of the respondent head teachers.

Other studies have shown that teachers have welcomed schools counselling because they felt they lacked the specialist skills, training and qualifications to provide such services themselves. Constraints on the time needed to address children"s wider emotional needs were also highlighted by schools staff as a benefit of employing schools counsellors. The primary school child in Nigeria does not seems to have been expose to proper and professional guidance and counselling, hence, underachievers" focus is limited. Academic underachievement is a common presenting symptom and has many different

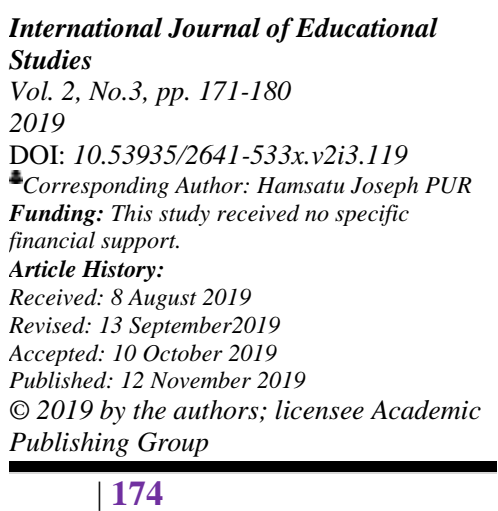
174 
causes. The disorders that describe academic underachievement are based on the child"s function in cognitive, academic, or behavioural domains. The disorders that are associated with academic underachievement are final common pathways that have different aetiologies and mechanisms. Multiple disorders are the rule because brain dysfunction in childhood usually affects multiple functions. Consequently, management programs must be individualized, comprehensive and address issues related to the child, school, and family. This study therefore aim at investigating the effect of individual counselling on underachievers in Maimusari Public Primary School in Jere Local Government Area of Borno State.

\section{Statement of the Problem}

Education at the primary school level is supposed to be the bedrock and the foundation towards academic excellence at the tertiary levels. Once a good foundation is laid at the primary level, the likelihood of experiencing academic problems at subsequent levels may be greatly minimized. Despite all efforts by their teachers, some primary school pupils are confronted with the problem of underachievement. Underachievement particularly in Nigeria is likely the root cause of the high rate of truancy hence, should be a great source of concern to all relevant authorities in Nigeria.

From the survey made by the researcher on preliminary investigations, it was observed that underachievement among the pupils of Maimusari primary school has a direct bearing with the insurgency. Many of them have been traumatised, depressed and confused as a result of losing family members to insurgency. It is evident that the pupils need proper counselling, which will help them to cope with the trauma they are going through.

\subsection{Objectives of the Study}

The objectives of the study are to determine:

1. the nature of underachievement among pupils in Maimusari primary school,

2. the causes of underachievement among pupils in Maimusari public primary school,

3. effect of individual counselling on academic performance of underachievers" pupils in Maimusari public primary school.

\subsection{Research Questions}

The following research questions were answered in the study:

4. What is the nature of underachievement among pupils in Maimusari public primary school?

5. What are the causes of underachievement among pupils Maimusari public primary school?

\subsection{Hypothesis}

$\mathrm{Ho}_{1}$ : Individual counselling has no significant effect on academic performance of underachievers" pupils in Maimusari public primary schools.

\section{Methodology}

The research design adopted in this study was the quasi-experimental research design. According to Dinardo (2008) quasi-experiment is an empirical study used to estimate the causal impact of an intervention on its target population. Two groups received counselling services on effect of individual counselling on underachievers in Maimusari primary school Jere Local Government Area, Borno State, where as one group served as a control group received counselling on child labour.

Purposive sampling method was employed to select 22 underachieving pupils from primary six out of 86 pupils in the class, following the fact that pupils in the lower classes may not be able to comprehend at their age. The research instrument that was used in the study was questionnaire designed by the researcher tagged Effect of Individual Counselling on Underachievers in Public Primary Schools (EICUPPS), and interview method was used to determine the causes of underachievement among pupils in Maimusari primary school. The instruments comprised of some sections which was divided into two parts; part one comprised of the causes of underachievement among pupils, while part two comprised of the effect of underachievement among pupils in Maimusari primary school. The instrument was based on four-point likert-type scale response. According to Osuala (1993) the scale is less frustrating to the respondent who wants to be truthful. The instrument was validated and made reliable by some experts in

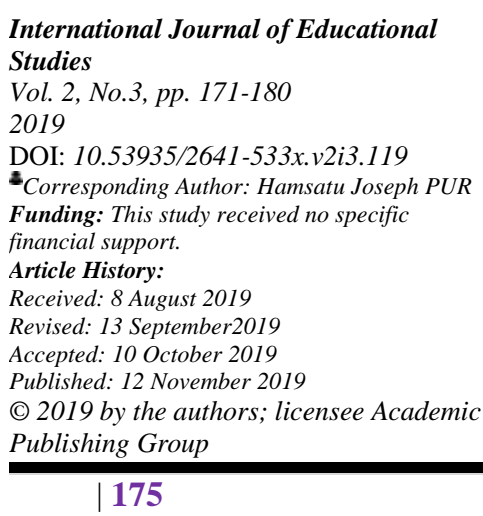


the department of education before it was administered to the respondent. Validation according Odo (1992) is the process of making sure that the instrument really test the variables or categories the researcher has claimed or want to test in her study. In this study therefore, the researcher, haven constructed the instrument provided the respondent with clear guideline of what is expected of them. The guideline included among other things, the purpose of the study, research question and hypothesis. This idea helped the respondent to determine which item actually elicited the information they intended to elicit. The researcher carried out a pilot study on a sample of intended respondent in the study area to see how they will likely react to the questionnaire in terms of clarity and ambiguity.

Reliability of instrument according to Odo (1992) involve the use of same measuring object to measure, test or evaluate the same object at different period in time and at each time receiving the same or similar result. The researcher therefore employed the test re-test techniques to determine the reliability of the instrument used in the present study. The researcher administered the instrument on ten respondents who had the same characteristics as the main survey group. The instrument was administered to get the post test scores. The reliability coefficient was 75 showed the instrument was reliable.

\subsection{Pre-Treatment Phase}

The Head Mistress called all the class teachers and introduced the researcher, asking the class teachers to co- operate with the researcher and give her the necessary information that she needed. The researcher explained to the class teachers about her mission and the various class teachers gave the researcher the list of the underachieving pupils in their class, call out the pupils to meet with the researcher. After which the researcher met and acquainted herself with participants, and had some fruitful discussion with them. The researcher thanked the participants and encouraged them to attend the next counselling session.

\subsection{Treatment Phase}

The researcher had one on one counselling session with each of the pupils and based on this the researcher discovered that the causes of this pupils underachievement was trauma, depression and anxiety. The researcher therefore grouped these pupils into two groups, though it was based on one-onone counselling, those that were depressed and traumatised form group 1 and those that have examination anxiety form group 2 while the control group form group 3 . The pupils were thought that guidance services are educational services aimed at helping the individual person to understand himself/herself well to be able to make appropriate decision, even in experience as an underachiever. These guidance services include appraisal services, counselling services, orientation services, placement services, referral services and follow up services. The researchers administered post-test to the same respondents to see the effect of treatment on underachievement among primary school pupils. The data generated was analysed using descriptive statistics (frequency and percentage) to analyse research question that is to determine the causes of underachievement, While Analysis of Covariance (ANCOVA) was used to analyse the effect of individual counselling on underachievement among public primary school pupils. The Univariate analysis is appropriate here because there is a normal score distribution in each cell in the pre-test and post-test. The pre-test serves as covariance while the post-test as dependent variable.

\subsection{Results}

The data collected were analysed and results are presented in the Tables below based on the research question and hypothesis raised in this study.

Table 1 reveals that majority $(54.5 \%)$ of the participants sometimes come late to school and $27.3 \%$

Vol. 2 . No.3, pp. 171-180

Vol. 2,

DOI: $10.53935 / 2641-533 x . v 2 i 3.119$

"Corresponding Author: Hamsatu Joseph PUR Funding: This study received no specific financial support.

Article History:

Received: 8 August 2019

Revised: 13 September 2019

Revised: 13 September 2019

Accepted: 10 October 2019

(C) 2019 by the authors; licensee Academic

Publishing Group

$$
\text { | } 176
$$
result it can be concluded that from the responses of the participant coming late to school causes underachievement among pupils.

The result further revealed that about $(40.9 \%)$ of the participants where never self-motivated to do their school work, $27.3 \%$ and $27.3 \%$ were rarely and sometimes self- motivated to do their school work 
respectively against only $1 \%$ that is always self-motivated. From this result it can be concluded that lack of self- motivation was one of the causes of underachievement among primary school pupils.

\begin{tabular}{|c|c|c|c|c|c|c|}
\hline \multirow[b]{2}{*}{ S/No. } & \multirow[b]{2}{*}{ Statement } & \multicolumn{5}{|c|}{ Responses } \\
\hline & & Never & Rarely & Sometime & Always & Total \\
\hline 1. & Coming late to School & 27.3 & & 54.5 & 18.2 & 22 \\
\hline 2. & $\begin{array}{l}\text { Self-motivation for school } \\
\text { work }\end{array}$ & 40.9 & 27.3 & 27.3 & 4.5 & 22 \\
\hline 3. & $\begin{array}{l}\text { Teachers make learning } \\
\text { interesting }\end{array}$ & 40.9 & 27.3 & 31.8 & & 22 \\
\hline 4. & $\begin{array}{l}\text { Doing school work } \\
\text { regularly }\end{array}$ & 22.7 & 45.5 & 31.8 & & 22 \\
\hline 5. & $\begin{array}{l}\text { Complete learning } \\
\text { material }\end{array}$ & 27.3 & 13.6 & 59.1 & & 22 \\
\hline
\end{tabular}

The study also revealed that about (40.9\%) responded that their teachers never made learning interesting, $27.3 \%$ reported that it is very rare for their teachers to make learning interesting against $31.8 \%$ that reported that sometimes their teachers made learning interesting. From this result it can be concluded that attitude of their teachers caused underachievement among primary school pupils.

Concerning the attitude of the participants toward doing their school work; it was majority (45.5\%) of the participants rarely do their school regularly and $22.7 \%$ of them never did their school work regularly against $31.8 \%$ who did their school work sometimes. From this result it can be concluded that not doing their school work regularly caused underachievement among primary school pupils.

It also shows the responses of the participant on how much they have access to complete learning materials; and majority (59.1\%) of the participant responded that most times they don ${ }^{\text {ee }} \mathrm{t}$ have complete learning material, $13.6 \%$ responded that they rarely do not have complete learning materials against $27.3 \%$ that always have complete learning materials. From this result it can be concluded that majority of the participant never had complete learning materials thereby leading to underachievement.

\begin{tabular}{|c|c|c|c|c|c|c|}
\hline \multirow[b]{2}{*}{ S/No. } & \multirow[b]{2}{*}{ Statement } & \multicolumn{4}{|c|}{ Response } & \multirow[b]{2}{*}{ Total } \\
\hline & & Never & Rarely & Sometime & Always & \\
\hline 1. & $\begin{array}{l}\text { Feel depressed } \\
\text { remembering parents }\end{array}$ & 27.3 & 4.5 & 63.3 & 4.5 & 22 \\
\hline 2. & $\begin{array}{l}\text { ExperiencingUnusual heart } \\
\text { beat before an } \\
\text { examination }\end{array}$ & 18.2 & 4.5 & 40.9 & 36.4 & 22 \\
\hline
\end{tabular}

Table 2 reveals that majority $(63.6 \%)$ of the participants responded that they sometimes feel depressed whenever they remember their parents, $4.5 \%$ always feel depressed against $27.3 \%$ and $4.5 \%$ who never and rarely feel depressed respectively whenever they remember their parents. From this result it can be concluded that majority of the participants feels depressed most time thereby making depression one of the perceived causes of underachievement.

It also reveals that majority $(40.9 \%)$ of the participant responded that sometimes before an examination they experience and unusual heartbeat and $36.4 \%$ responded that they always experience unusual heartbeat before an examination against $18.2 \%$ and $4.5 \%$ that never and rarely experience unusual heartbeat respectively. This result it can be concluded that the responses of the participant anxiety is perceived to be one of the causes of underachievement among primary school pupils.

$\mathrm{Ho}_{1}$ : Individual counselling has no significant effect on academic performance of underachievers" pupils in Maimusari public primary schools.

Studies

Vol. 2, No.3, pp. 171-180

2019

Corresponding Author: Hamsatu Joseph PUR Funding: This study received no specific

financial support.

Received: 8 August 2019

Revised: 13 September2019

Accepted: 10 October 2019

Published: 12 November 2019

(C) 2019 by the authors; licensee Academic

Publishing Group 
Table-3. Mean and Standard Deviation of Effect of Individual Counselling on Underachievers

\begin{tabular}{cccccc}
\hline Group & Mean Pre-test & $\mathbf{N}$ & Mean Post-test & SD Pre-test & SD Post-test \\
\hline Treatment & 90.91 & 11 & 101.00 & 13.487 & 8.318 \\
Control & 98.00 & 11 & 98.00 & 11.00 & 11.00 \\
\hline
\end{tabular}

Table-4. ANCOVA Test Between-Subjects on Effects of individual counselling on Underachievers

\begin{tabular}{lllllll|l}
\hline Source & $\begin{array}{l}\text { Type III Sum } \\
\text { of Squares }\end{array}$ & Df & $\begin{array}{l}\text { Mean } \\
\text { Square }\end{array}$ & F & Sig. & $\begin{array}{l}\text { Noncent } \\
\text { Parameter }\end{array}$ & $\begin{array}{l}\text { Obser } \\
\text { ved } \\
\text { Power }\end{array}$ \\
\hline $\begin{array}{l}\text { Corrected } \\
\text { Model }\end{array}$ & $41.069^{\text {a }}$ & 24 & 1.711 & 2.338 & 0.032 & 56.102 & 0.897 \\
$\begin{array}{l}\text { Intercept } \\
\text { Causes }\end{array}$ & 11.622 & 1 & 11.622 & 15.877 & 0.001 & 15.877 & 0.965 \\
& 41.069 & 24 & 1.711 & 2.338 & 0.032 & 56.102 & 0.897 \\
$*$ Effect & & & & & & & \\
$\begin{array}{l}\text { Error } \\
\text { Total }\end{array}$ & 13.909 & 19 & 0.732 & & & & \\
$\begin{array}{l}\text { Corrected } \\
\text { Total }\end{array}$ & 535.000 & 44 & & & & & \\
\hline Note: a. R Squared $=0.747$ (Adjusted R Squared $=0.427$ ), b. Computed using alpha $=0.05$. & \\
\hline
\end{tabular}

Table 4 above tagged "ANCOVA Tests of Between-Subjects Effects of counselling on underachievers" displays result obtained from covariant control of the experiment with post and pre-test experiment. The result obtained in this analysis reveals that at $\mathrm{F}_{(2,15)}$ and at 0.05 level of significant there was a p-value of $0.032<0.05$, implying that there is a significant effect of the group on the test subjects (post-test and pre-test). The test was carried out using main effect interact and error of type III was found out to be only 13.9. The result shows an intercept value of normality of 11.622 . The sum of squares between causes and effect of counselling was 41.069, at an observed power of 0.897 .

Since at $p<0.05$ there was a $p$ - value of 0.032 , which is less than 0.05 at $F_{2,15}$. We can then conclude that individual counselling has a significant effect on underachievers in public primary schools. This means that the null hypothesis is thereby rejected and the alternate accepted, which now states as "individual counselling has a significant effect on underachievers in public primary schools".

\subsection{Summary of Findings}

1. The study reveals that there were incidences of underachievement among pupils in Maimusari primary school in Maiduguri, Borno State.

2. It was discovered that coming late to school, not having complete learning material, depression, anxiety and teachers attitude in the class room were the major causes of underachievement in Maimusari primary school.

3. The study also revealed that individual counselling has helped the pupils in overcoming their learning barriers.

\section{Discussion}

Findings from data analysed with regards to research questions and hypothesis are presented thus: With reference to research question 1 which states that; what are the causes of underachievement? Item 1 , $6,12,14,22$ answers the research question 1 ; the result revealed that $72.7 \%$ of the participants come late to school, $68.2 \%$ responded that they are not self-motivated to do their school work, and $59.1 \%$ revealed that they most time lack

]complete learning materials, while $68.2 \%$ also revealed that their teachers don "et make learning interesting. Specifically, item 25 and 28 further revealed that depression and anxiety also causes underachievement among pupils. These conforms with statement of Ryan which states that; underachievement in any academic area can be identified: (1) their inadequate understanding of how to select, adapt, and monitor strategies for learning; and (2) their insufficient motivation to apply actively the understanding they have (Ryan \& Connell, 1989). 
With respect to the hypothesis which states that; individual counselling has no significant effect on underachievers in public primary schools. Finding revealed that individual counselling has a significant effect on underachievers, therefore the null hypothesis was rejected, by implication there was an improvement in the post-test scores of the treatment group against the post-test score of the control group. These results provide very strong support for the conclusion that school counselling interventions that focus on the development of cognitive, social, and self-management skills can result in sizable gains in student academic achievement as stated by Brigman and Campbell (2003).

\section{Conclusion}

It was therefore concluded that individual counselling has significant effect on underachievement among pupils of public primary school in Maiduguri, Borno State, Nigeria.

\section{Recommendations}

From the findings the following recommendations were made:

1. Class teachers need to be oriented on how to identify underachieving pupils in their various classes and inform the appropriate authority for proper management.

2. The school authority either through the parent teacher association meetings should educate the parents on the importance of preparing their wards early for school, providing them with complete prescribed learning materials. The school authority should train and retrain their teachers on teacher/pupils relationship to enhance learning and reduce the level of anxiety and depression among pupils.

3. There is need for the stakeholders to make provision for active counselling unit in every school.

\section{References}

Akinade, E. A. (2012). Modern behaviour modification, principles and practices. Ibadan: Bright Way Publishers.

Alzahrani, I., \& Woollarrd, J. (2013). The role of the constructive learning theory and collaborative learning environment on Wiki classroom, and the relationship between them. Paper presented at the International Conference for e-Learning \& Distance Education.

Bergin, J. J., Miller, S. E., Bergin, J. W., \& Koch, R. E. (1990). The effects of a comprehensive guidance model on a rural school's counseling program. Elementary School Guidance \& Counseling, 25(1), 37-45.

Bond, T. (2004). Ethical guidelines for researching counselling and psychotherapy. Wales, England: British Association for Counselling and Psychotherapy.

Brigman, G., \& Campbell, C. (2003). Helping students improve academic achievement and school success behavior. Professional School Counseling, 7(2), 91-99.

Cheek, J. R., Bradley, L. J., Reynolds, J., \& Coy, D. (2002). An intervention for helping elementary students reduce test anxiety. Professional School Counseling, 6(2), 162-164.

Connor, D. F. (2002). Aggression and anti-social behavior in children and adolescents, research and treatment. London: The Guilford Press.

Dinardo, J. (2008). Natural experiments and quasi-natural experiments. The New Palgrave Dictionary of Economics, 3(7), 856-859.

Donald, D., Lazarus, S., \& Lolwana, P. (2006). Educational psychology in social context. Cape Town, South Africa: Oxford University Press.

Gysbers, N. C. (2001). School guidance and counseling in the 21st century: Remember the past into the future. Professional School Counseling, 5(2), 96-106.

Gysbers, N., \& Henderson, P. (2006). Developing and managing your school guidance program (4th ed.). Alexandria, VA: American School Counseling Association.

Kolo, F. D. (2001). Elements of psychological testing for counsellors and psychologists. Zaria: Ahmadu Bello Co.

Matthews, M. S., \& McBee, M. T. (2007). School factors and the underachievement of gifted students in a talent search summer program. Gifted Child Quarterly, 51(2), 167-181.Available at: https://doi.org/10.1177/0016986207299473.

International Journal of Educational Studies

Vol. 2, No.3, pp. 171-180

2019

DOI: $10.53935 / 2641-533 x . v 2 i 3.119$

Corresponding Author: Hamsatu Joseph PUR Funding: This study received no specific financial support.

Article History:

Received: 8 August 2019

Revised: 13 September 2019

Accepted: 10 October 2019

Accepted. 10 October 2019

Publish: 2019 by the authors; 2019

Publishing Group
Moja, T. (2000). Nigeria education sector analysis, an analytical synthesis of performance and main issues. New York: World Bank.

Odo, O. M. (1992). Guide to proposal writing in social and behavioural science. Enugu: Snap Press Ltd.

Osuala, E. C. (1993). Research methodology. Benin: Africana-Fep Publishers.

Pattison, J. (2007). Representativeness and humanitarian intervention. Journal of Social Philosophy, 38(4), 569-587.Available at: https://doi.org/10.1111/j.1467-9833.2007.00399.x.

Rayneri, L. J., Gerber, B. L., \& Wiley, L. P. (2006). The relationship between classroom environment and the learning style preferences of gifted middle school students and the impact on levels of performance. Gifted Child Quarterly, 50(2), 104118.Available at: https://doi.org/10.1177/001698620605000203.

Reis, S. M., \& McCoach, D. B. (2002). Underachievement in gifted and talented students with special needs. Exceptionality, 10(2), 113-125.Available at: https://doi.org/10.1207/s15327035ex1002_5.

Reiss, S. (2008). The normal personality: A new way of thinking about people. New York: Cambridge University Press. 
Ruel, M. B. (1997). Belief, ritual and the securing of life: Reflexive essays on a Bantu religion. London: Academic Press.

Ryan, R. M., \& Connell, J. P. (1989). Perceived locus of causality and internalization: Examining reasons for acting in two domains. Journal of Personality and Social Psychology, 57(5), 749-761.Available at: https://doi.org/10.1037/0022-3514.57.5.749.

Scarborough, J. L., \& Luke, M. (2008). School counselors walking the walk and talking the talk: A grounded theory of effective program implementation. Professional School Counseling, 11(6), 2156759X0801100607.Available at: https://doi.org/10.5330/psc.n.2010-11.404.

Shaterloo, A., \& Mohammadyari, G. (2011). Students counselling and academic achievement. Procedia - Social and Behavioral Sciences, 30, 625-628.Available at: https://doi.org/10.1016/j.sbspro.2011.10.121.

Sink, C. A., \& Stroh, H. R. (2003). Raising achievement test scores of early elementary school students through comprehensive school counseling programs. Professional School Counseling, 6(5), 350-364.

Standard, R. P. (2003). High school graduation rates in the United States, implications for the counseling profession. Journal of Counseling and Development, 81(2), 217-221.Available at: https://doi.org/10.1002/j.1556-6678.2003.tb00245.x.

Sunil, K., \& Madhuri, K. (2005). Symposium on developmental and behavioural disorders-II. Indian Journal of Paediatrics, 72, 45-53.

International Journal of Educational

Studies

Vol. 2, No.3, pp. 171-180

2019

DOI: $10.53935 / 2641-533 x . v 2 i 3.119$

Corresponding Author: Hamsatu Joseph PUR

Funding: This study received no specific

financial support.

Article History:

Received: 8 August 2019

Revised: 13 September2019

Revised. 13 September 1019

Accepted. 10 October 2019

(C) 2019 by the authors; licensee Academic

Publishing Group 